\title{
LOCAL CITIZEN INITIATIVES IN POLAND: THE DISPARITY IN SIGNATURE REQUIREMENTS
}

\author{
Dorota Lis-Staranowicz*, Monika Giżyńska**
}

\begin{abstract}
In legal doctrine, attention is drawn to the relationship between instruments of direct democracy and the signature requirement, because the latter may block the activity ofcitizens. Therefore, this paper focuses on signature requirements of local citizen' initiatives (LCI), which is also analyzed from the perspective of the principle of equality. We identify: thelegal threshold of support (LTS) and the actual threshold of support (ATS). The legal threshold is construed as the statutory requirement of support (quantified or specified as a percentage), whereas the actual threshold of support is the quotient of the number of signatures required and the total number of residents in a given district. With respect to the LCI, a district is an area of a municipality, poviat and voivodship. The ATS is an indicator used by us to study the principle of equality.
\end{abstract}

Key words: direct democracy, local citizens' initiatives, signature requirements, the legal threshold of support, the actual threshold of support

* Ph.D. hab., Head of Constitutional Law Department, Faculty of Law and Administration, University of Warmia and Mazury in Olsztyn, staran@uwm.edu.pl, ORCID: 0000-0002-2118-3761.

** Ph.D., Department of Constitutional Law, Faculty of Law and Administration, University of Warmia and Mazury in Olsztyn, monika.gizynska@uwm.edu.pl, ORCID: 0000-0002-5483-9878. 


\section{INTRODUCTION}

The purpose of this paper is to present the local citizens' initiative (LCI) in Poland, in particular the so-called signature requirements. The concept and value of local self-government as well as participation of citizens in exercising power and making decisions have been the subject of numerous scholarly publications. They mainly presented examples of local residents' activity, changing the countenance of a city or a region ${ }^{1}$, yet also the absence of their broader involvement ${ }^{2}$. The problems of local participatory democracy have been studied from the point of view of economy, law and management, as well as sociology. One must agree withthe view that: "Democracy is a dynamic, protean concept and a constantly developing reality. Since the 1990s, many democracies have moved in one way or another towards more participatory citizens' involvement and a common trend towards increasing citizen engagement can be observed [...]. The introduction of democratic innovations that increase and deepen citizen participation in political will-formation and decision making is now a common policy of democratic governments"3. Admittedly, "the constitutionalization of the concept of direct democracy makes it possible to appeal to all known institutions of this form of democracy, but only if their nature and procedures are specified in the provisions of the Constitution and extended at the statutory level"4. The task of public authorities is to open up the decision-making process to the stakeholders at the local

1 Kees Koonings, Strengthening Citizenship in Brazil's Democracy: Local Participatory Governance in Porto Alegre, Biulletin of Latin American Research 23 (2004): 79-99.

2 Gema Sanches Medero, Gema y Pastor Albaladejo, The Quality of Participatory Processes in the Urban Redevelopment Policy of Madrid City Council, Lex Localis 16 (2018): 864. DOI: http://10.4335/16.4.841-872.

3 Brigitte Geissel, Ank Michels, Participatory Developments in Majoritarian and Consensus Democracies, Representation 54 (2018): 129. DOI: http://10.1080/ 00344893.2018.1495663.

4 Monika Giżyńska, The Shortcoming of a Nationwide Referendum. Reflecting upon the Possibility of Introducing an Abrogative Referendum into the Polish Legal System, Toruńskie Studia Polsko-Włoskie XIV (2018): 85. DOI: http://dx.doi.org/10.12775/ TSP-W.2018.006. 
level ${ }^{5}$. On the one hand, accomplishing that task consists in involving not only citizens of the state, but also residents (which is of particular importance in the era of migration problems), while on the other hand, in introducing new instruments of direct and indirect democracy. The local citizens' initiative is one such instruments ${ }^{6}$. The LCI seems to be attractive for young citizens who do not engage in state policy, but do engage in local affairs ${ }^{7}$.

We do not intend to carry out a comprehensive analysis of the institution in question since it was regulated by the Act of 11 January, 2018 on the amendment of certain laws to increase the participation of citizens in the process of selecting, functioning and controlling certain public bodies (hereinafter: the Act of $2018^{8}$ ). In turn, the regulations regarding the LCI entered into force on November 26, 2018. In our opinion, it is therefore too early to fully assess it. The Act of 2018 removed inequality before the law, as the LCI was present in Poland, however it was not of a universal nature. The right to submit a draft resolution to self-government bodies was guaranteed only by certain municipalities (in Polish: gmina), poviats and voivodships. That right arose under their local statutes, under which the so-called signature requirements (SR) varied. It is suggested in legal science that more attention should be paid to both the SR and the procedure for collecting signatures ${ }^{9}$ because they may block the application of direct

5 John Dryzek, Democratization as Deliberative Capacity Building, Comparative Political Studies 42 (2009): 1379-1402. DOI: https://doi.org/10.1177/0010414009332129.

6 Piotr Ziętarski, Aspekty aksjologiczne partycypacji społecznej a obywatelska inicjatywa uchwałodawcza, In: Obywatelska inicjatywa uchwałodawcza w procesie stanowienia aktów prawa miejscowego, Piotr Zientarski, Elżbieta Mreńca, ed., Warszawa: Kancelaria Senatu, 2018, 25.

7 Henrik Serup Christensen, Maija Jäske, Maija Setälä, Elias Laitinen, The Finnish Citizens' Initiative: Towards Inclusive Agenda-Setting?, Scandinavian Political Studies 40 (2017): 411-433. DOI: 10.1111/1467-9477.12096.

Young residents of one of the cities in Poland actively engaged in the project of organizing a Hip-Hop festival. Using social media, they promoted the project among young people who voted for it under the citizens' budget procedure. It was eventually included in the city budget, and the concert was financed out of public funds.

8 Journal of Laws, item 130.

9 Richard Ellis, Signature Gathering in the Initiative Process: How Democratic Is It?, Montana Law Review 64 (2003): 35-64. December 4, 2018, https://scholarship.law. 
democracy instruments. Therefore, signature requirements are the focus of this paper.

For the purposes of the paper we identify: a) the legal threshold of support (LTS) and b) the actual threshold of support (ATS). The legal threshold is construed as the statutory requirement of support (quantified or specified as a percentage). In turn, the actual threshold of support is the quotient of the number of signatures required and the total number of residents of a given district. With respect to the LCI, a district is an area of a municipality, poviat and voivodship. The above mentioned goals require a normative analysis of the legal status quo laid down by statutory provisions and local laws (dogmatic method). We also employ the quantitative method, setting the ATS (the actual threshold of support). Therefore, we examine the percentage ratio of the legal signature requirement to the number of inhabitants of a local government unit. The subject of quantitative research is limited to the least and most populated communes, poviats, as well as cities with poviat rights. The number of inhabitants is based on statistical data published by Statistics Poland in 2019 (current as at December 31,2018). We also refer to legal frameworks in force in the EU and selected EU member states. However, we employ the comparative legal method only to the extent necessary to outline the background of the title phenomenon.

\section{LEGAL BACKGROUND}

At the outset of our analysis let us note that not less than one million citizens of the European Union (EU) who are nationals of a significant number of Member States may take the initiative of inviting the Commission, within the framework of its powers, to submit any appropriate proposal on matters where citizens consider that a legal act of the Union is required for the purpose of implementing the Treaties ${ }^{10}$. That institution was intended to strengthen representative and participatory democracy

umt.edu/mlr/vol64/iss1/4. Tomoya Tajika, Signature Requirements for Initiatives, Journal of Theoretical Politics 30 (2018): 451-476. DOI: 10.1177/0951629818791035.

10 Art. 11(4) of the Treaty on European Union. 
in the Union, being the only "true democratic innovation" of the Lisbon Treaty ${ }^{11}$. At the national level, the Constitution of the Republic of Poland of April 2, 1997 granted citizens the right to submit a draft law to parliament. Article $118 \mathrm{sec} .2$ of the Constitution provides that the legislative initiative is also vested in a group of at least 100,000 citizens who have the right to vote in elections to the Sejm. The procedure in this case is set forth by the Act of June 24, 1999 on the exercise of the legislative initiative by citizens ${ }^{12}$. However, the Constitution does not guarantee citizens the right to submit a draft law to local self-government bodies, although the functioning thereof is regulated under Chapter VII. Yet, it provides citizens with the right to participate in local elections, the right to participate ina local referendum and the right to petitions ${ }^{13}$.

The right to submit a draft resolution is, as granted by the Act of 2018, of a collective nature, vested in a group of residents of a municipality, poviat and voivodship, who have the right to vote in elections to a legislative body (municipal council, poviat council and voivodship parliament (in Polish: sejmik województwa) ${ }^{14}$. In turn, the legislative body is obliged to examine the draft at the first session, but no later than 3 months afterits submission. The Act does not provide for an obligation to adopt it. This means that citizens are only entitled to a claim to initiate theproceedings regarding a resolution and submit an initiative for consideration by the legislative body. Therefore, the LCI may not be regarded as an instrument of direct democracy sensu stricto. It is of a mixed nature "as it is based on a proposal (draft) put forward by the residents of a municipality

11 Bruno Kaufmann, ed., Podręcznik europejskiej inicjatywy obywatelskiej. Przewodnik po zasadach pierwszego ponadnarodowego narzędzia demokracji bezpośredniej na świecie, Luxembourg: Green European Foundation, 2010, 5.

12 Journal of Laws of 1999, No. 62, item 688, as amended.

13 Agnieszka Turska-Kawa, Waldemar Wojtasik, Direct Democracy in Poland. Between Democratic Centralism and Civic Localism, Journal of Comparative Politics 11 (2018): 18-29.

14 Hubert Izdebski, Prawne podstawy obywatelskiej inicjatywy uchwałodawczej, In: Obywatelska inicjatywa uchwałodawcza w procesie stanowienia aktów prawa miejscowego, Piotr Zientarski, Elżbieta Mreńca, ed., Warszawa: Kancelaria Senatu, 2018, 12; Dorota Lis-Staranowicz, La proposta di deliberazione (a livello locale) di iniziativa popolare in Polonia, In: La democrazia diretta in Italia, Polonia e Unione europea, Gian Candido De Martin, Andrzej Szmyt, Piero Gambale e Maciej Serowaniec, ed., Roma: Luiss University Press, 2020, 541. 
(an element of directness), while the final decision regarding approval (rejection) of a specific initiative (draft) is taken by the [...] decision-making municipal body $[\ldots]^{\prime 15}$. This state of affairs allows us to regard the LCI asan instrument of semi-direct democracy ${ }^{16}$.

\section{INEQUALITY BEFORE THE LAW}

Under the legal framework preceding the entry into force of the Act of 2018, the right was guaranteed, as referred to above, by the statutes of local government units. Therefore, it was not universalsince not all local governments introduced the LCI reinforcingcivic participation. The absence of statutory regulation was not negatively assessed as local governments developed their own original solutions meeting the needs ofresidents ${ }^{17}$. On the other hand, the absence of statutory regulation created inequality of residents of local government units. The first one resulted from the absence of regulation as such, blocking the citizens' way of submitting their own draft resolutions to the council. The other inequality was the consequence of a diversified threshold of support for citizens' resolution-makinginitiatives (signature requirements). Based on the regulations applicable in large cities (we limited to the cities and townsthat are the seat of voivodship authorities or voivodship parliament), it can be observed that the SR was established either as a percentage or quantifiedas follows ${ }^{18}$ :

15 Dawid Ziółkowski, Obywatelska inicjatywa uchwałodawcza jako instrument partycypacji społecznej, Zeszyt Studencki Kół Naukowych Wydziału Prawa i Administracji UAM 8 (2018): 335. December 3, 2018, http://cejsh.icm.edu.pl/cejsh/element/bwmeta1. element.desklight-12fe50bc-d98e-4660-b2bb-8bc0b2934c6e.

16 Piotr Uziębło, Demokracja Partycypacyjna, Gdańsk: Centrum Badań Społecznych, 2009, 42.

17 Grzegorz Makowski, Obywatelska inicjatywa uchwałodawcza - prawo i praktyka, In: Dyktat czy uczestnictwo? Diagnoza partycypacji publicznej w Polsce, Anna Olech, ed., Warszawa: Instytut Spraw Publicznych, 2012, 288-304.

18 All data and indicators [as cited in:] Piotr Jać, Obywatelska inicjatywa uchwałodawcza, In: Partycypacja obywatelska-decyzje bliższe ludziom, Agnieszka Maszkowska, Katarzyna Sztop-Rutkowska, ed., Białystok: Fundacja Laboratorium Badań i Działań Społecznych "SocLab”, 2013, 156. 
1) Białystok: 2000 eligible residents (hereinafter: persons) with the right to vote in electionsto city authorities, were able to submit a draft resolution (which constituted $0.87 \%$ of all city residents - the actual threshold of support);

2) Bydgoszcz: 1000 persons (actual threshold of support of $0.35 \%$ ATS);

3) Gdańsk: 2000 persons ( $0.56 \%$ ATS);

4) Katowice: 500 persons ( $0.20 \%$ ATS);

5) Kielce: 2000 persons (1.23\% ATS);

6) Kraków: 4000 persons (0.68\% ATS);

7) Lublin: 1000 persons (0.37\% ATS);

8) Łódź: 6000 persons (1.03\% ATS);

9) Olsztyn: 150 persons (0.11\% ATS);

10) Poznań: 5000 persons ( $1.18 \%$ ATS);

11) Rzeszów: 500 persons (0.36\% ATS);

12) Szczecin: 400 persons (0.13\% ATS);

13) Toruń: 150 persons ( $0.09 \%$ ATS);

14) Opole: 500 persons (0.52\% ATS);

15) Warszawa: 15.000 persons (1.12\% ATS);

16) Wroctaw: a group of at least $1 \%$ of residents with the right to vote and registered in the permanent register of voterswas able to submit a draft resolution;

17) Zielona Góra: 400 persons $(0,43 \% \text { ATS })^{19}$;

18) Bytom: at least $10 \%$ of eligible residents (it is not the seat of the voivodshipauthorities, but it has a high threshold of support ${ }^{20}$;

19 All data and indicators [as cited in:] Piotr Jać, Obywatelska inicjatywa uchwałodawcza, In: Partycypacja obywatelska-decyzje bliższe ludziom, Agnieszka Maszkowska, Katarzyna Sztop-Rutkowska, ed., Białystok: Fundacja Laboratorium Badań i Działań Społecznych "SocLab", 2013, 156-157.

20 Resolution No. XVII/255/03 of the City Council in Bytom dated December 17, 2003 regarding the adoption of the Statute of the City of Bytom (i.e. Journal of Laws of the Silesian Voivodship of 2013, item 1958). 
The above data, collected in cities and large town $\mathrm{s}^{21}$, indicates that the threshold of support for a residents' draftranged from very low, e.g. $0.09 \%$ (Toruń) and $0.11 \%$ (Olsztyn) to very high, e.g. $10 \%$ of eligible residents (Bytom). In this context, it must be assumed that high thresholds of support could discourage residents from submitting draft resolutions, obstructing the activity of the local community. In the period between 2014 and 2018, the residents most willing to resort to it were those of Toruń (16 draft resolutions), Lublin (14 draft resolutions), Łódź (13 draft resolutions). In other large cities, several drafts were submitted, for example in Katowice (4 drafts), Gdańsk/Białystok/Olsztyn (3 drafts), Wrocław and Zielona Góra (2 drafts), Warsaw and Kraków (1 draft). The effectiveness of the citizens' resolution-making initiative in large cities was low, e.g. in Łódź one resolution was adopted at the initiative of the citizens, and three in Torun ${ }^{22}$. The subject matter of citizens' resolution-making initiatives in 2014-2018 concerned $^{23}$ : local taxes, changing street names, building a monument, building a kindergarten, building a nursery, building a gymnasium, building street traffic lights, building bicycle paths, building a water supply system, fees for using municipal transport, financing infertility treatment by IVF method, sale of municipal property, combining cultural centres, sale of alcohol, cleanliness of air, free school meals, market fee, prohibition to allow circuses with animals in a city ${ }^{24}$.

21 There is no comprehensive LCI research in Poland. Although that institution has been discussed in numerous scholarly publications, there are no detailed studies in Poland in terms of its usefulness and effectiveness.

22 Information obtained from the Office of the Lublin City Council, Office of the Toruń City Council, Office of the Lódź City Council, Office of the Katowice City Council, Office of the Bialystok City Council, Office of the Olsztyn City Council, based on citizens' activity in 2014-18.

23 Data refers only to cities that are the seat of voivodship authorities.

24 Information obtained from: the Office of the Lublin City Council, Office of the Torun City Council, Office of the Łódź City Council, Office of the Katowice City Council Office, Office of the Bialystok City Council, Office of the Olsztyn City Council, Office of the Rzeszów City Council, Office of the Kielce City Council, based on citizens' activity in 2014-2018; see more Dorota Lis-Staranowicz, La proposta di deliberazione (a livello locale) di iniziativa popolare in Polonia, 546. 
The local citizens' initiative was of marginal importance for the development of participatory democracy in Poland ${ }^{25}$. "This refers to both their normative basis and the practice of applying them in public life. There are also no premises which would allow an evaluation of the progressive or regressive nature of the way these very different forms of citizens' participation function in the decision-making process at the local level"26. In our opinion, the marginal importance resulted from the lack of awareness of the LCI. It was not well known to Polish citizens, which could have hampered its effectiveness and usefulness ${ }^{27}$. Moreover, only $20 \%$ of municipalities in Poland guaranteed a group of citizens the right to submit a draft resolution. The LCI was almost absent in voivodship self-governments (only one voivodship self-government resolved to introduce it), and also rare in poviats $(1.5 \% \text { of poviats })^{28}$. That instrument was not, as the examples of large cities show, often applied by residents, and its effectiveness was negligible. However, a number of spectacular LCI achievements in smaller municipalities should be noted, e.g. constructing a hospital in one of Warsaw's districts or introducing a participatory budget at the initiative ofthe residents.

\section{UNEQUAL TREATMENT}

The situation changed with the entry into force of the Act of 2018. First of all, the LCI is the right of residents eligible to vote in elections to territorial self-government bodies. In turn, the right to vote is vested in a Polishcitizen and a citizen of the European Union (who is not a Polish citizen) aged 18 or over and who resides in the area of a mu-

25 Andrzej Piasecki, Twenty Years of Polish Direct Democracy at the Local Level, In: Local Direct Democracy in Europe, Theo Schiller, ed., Wiesbaden: GWV Fachverlage $\mathrm{GmbH}, 2011,135$.

26 Ibidem.

27 Mirko Pečarič, Some Initiatives for Modernization of Local Democracy, Lex Localis 11 (2013): 275. DOI: https://doi.org/10.4335/11.3.271-291(2013).

28 Anna Ścisłowska, Waldemar Duczmal, Obywatele piszą lokalne prawo? Dlaczego nie!. December 29, 2019, http://serwis.mamprawowiedziec.pl/2016/11/Obywatele-pisza-lokalne-prawo.html. 
nicipality, poviat and voivodship ${ }^{29}$. In addition, the Act of 2018 amended three local government acts, introducing the citizens' resolution-making initiative to them, i.e. Article 41a of the Act of March 8, 1990 on municipal self-government ${ }^{30}$; Article 42a of the Act of June 5, 1998 on poviat self-government ${ }^{31}$; Article 89a of the Act of June 5, 1998 onvoivodship self-government ${ }^{32}$. Moreover, local government laws contain very general provisions on the said institution. They specify the number of eligible residents to submit a draft resolution. Then they stipulate that a draft resolution submitted by residents shall be addressed by the municipal council, poviat council or voivodship parliament at the next session after submitting the draft, however not later than after 3 months of its submission. A committee of the resolution-making initiative that has the right to indicate persons authorized to represent the committee in the proceedings of the municipal council, poviat council or voivodship parliamentacts on behalf of citizens. Most importantly, the municipal council, poviat council and voivodship parliament lays down, by way of a resolution, detailed rules for the implementation of a citizens' initiative: appointing committees for resolution-making initiatives, promoting citizens' resolution-making initiatives, requirements that submitted drafts must meet. As a result, the LCI is provided for in two ways, i.e. in an act of the parliament and a resolution of the local government. What the legislatordefinitively provided forwere only the SR, specifying them in terms of numbers, as well as theobligation to examine the LCI within a given period of time. In turn, a resolution of the local government unit sets out a detailed procedure for the implementation of the citizens' legislative initiative. In this respect, the legislator left a wide margin of regulatory discretion to the local government. Moreover, it did not specify the time limit for adopting resolutions by the local government, whichwe believe to be a mistake. It must be noted that unless such resolutions are adopted, residents are unable toexercise their right (in Poland, there were

29 The Act of January 5, 2011 - the Electoral Code (consolidated text: Journal of Laws of 2018, item 754, as amended).

30 Consolidated text: Journal of Laws of 2018, item 944, as amended.

31 Consolidated text: Journal of Laws of 2018, item 995, as amended.

32 Consolidated text: Journal of Laws of 2018, item 913, as amended. 
16 self-government voivodships, 314 poviats, 66 towns with administrative rights of a poviat and 2477 municipalities $^{33}$, and not all territorial self-government units performed the obligation incumbent thereon, e.g. on January 1, 2019, only 3 out of 16 voivodship local governments adopted resolutions specifying a detailed procedure for the implementation of the citizens' initiative).

\subsection{Voivodship (16 voivodships)}

A group of at least 1,000 residents of a voivodship eligible to vote in elections to alegislative body may submit a draft resolution to the voivodship parliament (Article 89a of the Act on voivodship self-government).

Table 1. Minimum numbers of residents forming the committee and residents entitled to submit a draft in voivodships

\begin{tabular}{|c|c|c|c|c|}
\hline Voivodship & $\begin{array}{l}\text { Number of } \\
\text { residents } \\
\text { (thousands } s^{34} \text { ) }\end{array}$ & $\begin{array}{c}\text { Minimum } \\
\text { number } \\
\text { of residents } \\
\text { entitled } \\
\text { to submit a draft }\end{array}$ & $\begin{array}{l}\text { Number of } \\
\text { residents forming } \\
\text { the committee } \\
\text { (minimum) }\end{array}$ & $\begin{array}{c}\text { Time limit } \\
\text { for collecting } \\
\text { signatures } \\
\text { for a draft }\end{array}$ \\
\hline $\begin{array}{l}\text { Mazowieckie } \\
\text { Voivodship }\end{array}$ & 5403.4 & $\begin{array}{c}1000 \mathrm{LTS}^{35} \\
\left(0.0185 \% \mathrm{ATS}^{36}\right)\end{array}$ & 5 residents & undetermined \\
\hline $\begin{array}{l}\text { Silesian } \\
\text { Voivodship }\end{array}$ & 4533.6 & $\begin{array}{l}\text { as above } \\
(0.022 \%)\end{array}$ & 5 residents & undetermined \\
\hline $\begin{array}{l}\text { Wielkopolskie } \\
\text { Voivodship }\end{array}$ & 3484.975 & $\begin{array}{c}\text { as above } \\
(0,0287 \%)\end{array}$ & $\begin{array}{l}\text { lack of } \\
\text { regulation }\end{array}$ & $\begin{array}{l}\text { lack of } \\
\text { regulation }\end{array}$ \\
\hline $\begin{array}{l}\text { Małopolskie } \\
\text { Voivodship }\end{array}$ & 3400.6 & $\begin{array}{l}\text { as above } \\
(0.0294 \%)\end{array}$ & 5 residents & undetermined \\
\hline
\end{tabular}

33 Legal framework as of January 1, 2019.

34 Population. Statistical Vademecum of Regional Civil Servant as of December 31, 2018, Central Statistical Office 2019.

35 Legal Threshold of Support.

36 Actual Threshold of Support. 


\begin{tabular}{|c|c|c|c|c|}
\hline Voivodship & $\begin{array}{c}\text { Number of } \\
\text { residents } \\
\text { (thousands }^{34} \text { ) }\end{array}$ & $\begin{array}{c}\text { Minimum } \\
\text { number } \\
\text { of residents } \\
\text { entitled } \\
\text { to submit a draft }\end{array}$ & $\begin{array}{l}\text { Number of } \\
\text { residents forming } \\
\text { the committee } \\
\text { (minimum) }\end{array}$ & $\begin{array}{c}\text { Time limit } \\
\text { for collecting } \\
\text { signatures } \\
\text { for a draft }\end{array}$ \\
\hline $\begin{array}{l}\text { Dolnośląskie } \\
\text { Voivodship }\end{array}$ & 2902,365 & $\begin{array}{c}\text { as above } \\
(0,0345 \%)\end{array}$ & $\begin{array}{l}\text { lack of } \\
\text { regulation }\end{array}$ & $\begin{array}{l}\text { lack of } \\
\text { regulation }\end{array}$ \\
\hline $\begin{array}{l}\text { Lódzkie } \\
\text { Voivodship }\end{array}$ & 2466.3 & $\begin{array}{c}\text { as above } \\
(0.0403 \%)\end{array}$ & 10 residents & undetermined \\
\hline $\begin{array}{l}\text { Pomorskie } \\
\text { Voivodship }\end{array}$ & 2333.5 & $\begin{array}{c}\text { as above } \\
(0.0428 \%)\end{array}$ & 10 residents & 3 months \\
\hline $\begin{array}{l}\text { Podkarpackie } \\
\text { Voivodship }\end{array}$ & 2129.0 & $\begin{array}{c}\text { as above } \\
(0.0469 \%)\end{array}$ & 5 residents & undetermined \\
\hline $\begin{array}{l}\text { Lubelskie } \\
\text { Voivodship }\end{array}$ & 2117.6 & $\begin{array}{c}\text { as above } \\
(0.0472 \%)\end{array}$ & 7 residents & undetermined \\
\hline $\begin{array}{l}\text { Kujawsko- } \\
\text {-pomorskie } \\
\text { Voivodship }\end{array}$ & 2082,935 & $\begin{array}{c}\text { as above } \\
(0,0480 \%)\end{array}$ & $\begin{array}{l}\text { lack of } \\
\text { regulation }\end{array}$ & $\begin{array}{l}\text { lack of } \\
\text { regulation }\end{array}$ \\
\hline $\begin{array}{l}\text { Zachodnio- } \\
\text {-pomorskie } \\
\text { Voivodship }\end{array}$ & 1701.0 & $\begin{array}{c}\text { as above } \\
(0.0587 \%)\end{array}$ & 10 residents & 90 days \\
\hline $\begin{array}{l}\text { Warmiń- } \\
\text { sko-mazurskie } \\
\text { Voivodship }\end{array}$ & 1429.0 & $\begin{array}{c}\text { as above } \\
(0.0699 \%)\end{array}$ & 15 residents & 90 days \\
\hline $\begin{array}{l}\text { Świętokrzyskie } \\
\text { Voivodship }\end{array}$ & 1241.5 & $\begin{array}{c}\text { as above } \\
(0.0805 \%)\end{array}$ & 5 residents & undetermined \\
\hline $\begin{array}{l}\text { Podlaskie } \\
\text { Voivodship }\end{array}$ & 1181.5 & $\begin{array}{c}\text { as above } \\
(0.0846 \%)\end{array}$ & 65 residents & 3 months \\
\hline $\begin{array}{l}\text { Lubuskie } \\
\text { Voivodship }\end{array}$ & 1014.5 & $\begin{array}{c}\text { as above } \\
(0.0985 \%)\end{array}$ & 7 residents & undetermined \\
\hline $\begin{array}{l}\text { Opolskie } \\
\text { Voivodship }\end{array}$ & 991,161 & $\begin{array}{l}\text { as above } \\
(0.1008)\end{array}$ & $\begin{array}{l}\text { lack of } \\
\text { regulation }\end{array}$ & $\begin{array}{l}\text { lack of } \\
\text { regulation }\end{array}$ \\
\hline
\end{tabular}

Source: Author's study, the legal status as of April 2020. 
The table above indicates that, first and foremost, so far only three voivodship parliaments (out of the total of 16) have adopted relevant resolutions regarding the detailed procedure for the implementation of the legislative initiative. Secondly, the legislator stipulated a rigid number of persons entitled to submit a draft, i.e. 1000 persons (statutory threshold of support). Thirdly, the diversification of voivodships in terms of the number of residents translates into the ability of residents to submit a draft: i.e. from $0.0185 \%$ of the Mazowieckie Voivodship residents to $0.1013 \%$ of the Opolskie Voivodship residents (actual threshold of support). The highest actual threshold of support is more than 5 times higher than the lowest one, which demonstrates the actual inequality of individual residents and regions. In other words, the statutory regulation maintains formal equality as the residents of each voivodship are able to submit a draft resolution to the voivodship parliament, and the number regarding support for a draft by residents is the same in every voivodship. However, the Act does not guarantee equality in material sense because the extent of support for a draft varies.

\subsection{Municipality (66 cities with poviat rights and 2,477 municipalities)}

The right to submit a draft resolution is vested in residents eligible to vote in elections to a legislative body (municipal council, city council) in a municipality: a) up to 5000 residents - at least 100 persons; b) up to 20000 residents - at least 200 persons; c) over 20000 residents - at least 300 persons (Article 41a of the Act on municipal government). 
Table 2. Minimum number of residents forming the committee and residents entitled to submit a draft in municipalities

\begin{tabular}{|l|c|c|c|c|}
\hline Municipality & $\begin{array}{c}\text { Number } \\
\text { of } \\
\text { residents }\end{array}$ & $\begin{array}{c}\text { Minimum number of } \\
\text { residents entitled to } \\
\text { submit a draft }\end{array}$ & $\begin{array}{c}\text { Number of } \\
\text { residents forming } \\
\text { the committee } \\
\text { (minimum) }\end{array}$ & $\begin{array}{c}\text { Time limit } \\
\text { for collecting } \\
\text { signatures for } \\
\text { the draft }\end{array}$ \\
\hline \multicolumn{5}{|c|}{ The smallest municipalities } \\
\hline Powidz & 2319 & (4.31\% residents ATS $\left.{ }^{39}\right)$ & $\begin{array}{c}5(0.22 \% \\
\text { residents) }\end{array}$ & 45 days \\
\hline $\begin{array}{l}\text { Krynica } \\
\text { Morska }\end{array}$ & 1303 & $100(7.67 \%)$ & lack of regulation & lack of regulation \\
\hline \multicolumn{5}{|c|}{ The biggest municipalities } \\
\hline Inowrocław & 73114 & $300(0.41 \%)$ & 3 persons & undetermined \\
\hline Piaseczno & 83792 & $300(0.36 \%)$ & 5 persons & 3 months \\
\hline \multicolumn{5}{|c|}{$\begin{array}{l}\text { City/town with poviat rights, } \\
\text { to which the provisions of the Act on municipal self-government apply }\end{array}$} \\
\hline Warsaw & 1777972 & $300(0.0168 \%)$ & 5 residents & undetermined \\
\hline Kraków & 771069 & $300(0.0391 \%)$ & 5 residents & undetermined \\
\hline Eódź & 682679 & $300(0.0439 \%)$ & 5 residents & 30 days \\
\hline Wrocław & 640648 & $300(0.0468 \%)$ & 7 residents & undetermined \\
\hline Ostołęka & 52262 & $300(0.5740 \%)$ & 10 residents & 60 days \\
\hline Sopot & 36046 & $300(0.8322 \%)$ & 5 residents & 50 days \\
\hline
\end{tabular}

Source: Autor's study, the legal status as of April 2020.

37 Population. Statistical Vademecum of Regional Civil Servant as of December 31, 2018, Central Statistical Office 2019.

38 Legal Threshold of Support.

39 Actual Threshold of Support. 
The legislator introduced three statutory thresholds of support for citizens' legislative initiatives: 100 persons, 200 persons and 300 persons. They are of a progressive nature. Such a solution was intended to reduce disparities between municipalities (towns/cities) due to population. In fact, this specific goal has not been fully accomplished. In Warsaw, a city of 1.7 million residents, adraft maybe submitted by at least 300 eligible persons, in the small town of Sopot (approx. 37 thousand) - also by 300 persons, while in Krynica Morska - the smallest municipality (approx. 1.3 thousand) - by 100 persons. This leads to significant differentiation as the actual LCI support threshold varies from 7.67\% in Krynica Morska (high actual threshold of support) to $0.0168 \%$ in Warsaw (low actual threshold of support). The lowest threshold of support is 400 times lower than the highest one. As a result, it can be expected that, first of all: a) the larger the city/municipality, b) the lower the actual threshold of support and c) the greater the activity of residents; secondly: a) the smaller thecity/ municipality, b) the higher the actual threshold of support and c) the lower the activity of residents ${ }^{40}$. However, the Act does not guarantee equality in a material sense because the extent of support for a draft varies.

\subsection{Poviat (314 poviats)}

The right to submit a draft resolution is vested in residents eligible to vote in elections to a legislative body (poviat council) in a poviat: up to 100000 residents - at least 300 persons; 2) in a poviat of over 100000 residents - at least 500 persons (Article 42a of the Act on poviat self-government).

40 We have not conducted research on the activity of citizens and the frequency of submissions of draft resolutions, since - based on the analyzed statutory provisions citizens are allowed to submit draft resolutions to the decision-making bodies elected in the elections on October 21, 2018. This period is too short to allow research on the activity of residents. 
Table 3. Disparities between poviats due to population and the minimum number of residents entitled to submit a draft in the poviats

\begin{tabular}{|l|c|c|c|c|}
\hline Poviat & $\begin{array}{c}\text { Number } \\
\text { of residents }\end{array}$ & $\begin{array}{c}\text { Minimum number } \\
\text { of residents entitled } \\
\text { to submit a draft }\end{array}$ & $\begin{array}{c}\text { Number of } \\
\text { residents forming } \\
\text { the committee } \\
\text { (minimum) }\end{array}$ & $\begin{array}{c}\text { Time limit } \\
\text { for collecting } \\
\text { signatures } \\
\text { for a draft }\end{array}$ \\
\hline \multicolumn{4}{|c|}{ The smallest poviat } \\
\hline Sejneński & 20092 & $\begin{array}{c}\text { 300 LTS } \\
(1.4391 \% \text { residents, ATS) }\end{array}$ & 5 persons & undetermined \\
\hline \multicolumn{5}{|c|}{ The largest poviat } \\
\hline Poznański & 390308 & $\begin{array}{c}500 \\
(0.1281 \%)\end{array}$ & 50 days \\
\hline
\end{tabular}

Source: Autor's study, the legal status as of April 2020.

The above indicates that the legislator introduced two thresholds of support for citizens' legislative initiatives in a Poviat: 300 persons and 500 persons. As in the case of municipalities, they were intended to reduce disparities between poviats due to population. The comparison of the smallest and the largest poviat shows that the disparities were not avoided, e.g. in the Poznański poviat (390,308 residents), a draft may be submitted by at least 500 eligible citizens, while in the Sejneński poviat $(20,092$ residents), the statutory threshold of support amounts to at least 300 citizens. Social support for a draft varies from $1.439 \%$ (the highest actual threshold of support) to $0.1281 \%$ of eligible residents (the lowest actual threshold of support). Thus, the highest actual threshold of support is 11 times higher than the lowest threshold. However, the Act does not guarantee equality in material sense because the extent of support for a draft varies.

41 Population. Population. Statistical Vademecum of Regional Civil Servant as of December 31, 2018, Central Statistical Office 2019. 
4.4. How does the UECI provided for in the EU Treaty

and the citizens' legislative initiative, the normative source

of which is the Constitution of the Republic of Poland compare?

The legal threshold of support of an initiative at the EU level is 1 million residents. In turn, the actual threshold, assuming that there are 512 million residents in the $\mathrm{EU}$, amounts to $0.1950 \%$. With respect to a citizens' legislative initiative, the legal threshold of support equals 100,000 . It may not be considered high as the actual threshold of support, with 38411,1 thousand residents of Poland, is at the level of $0.26 \%$. It is not too high in comparison to other countries, e.g. "The number of citizens required for a legislative initiative varies between 1000 citizens (Liechtenstein), 5000 voters (Slovenia), 10000 voters (FYROM ${ }^{42}$ ), 20.000 electors (Albania), 30.000 (Georgia), 50.000 citizens (as in Lithuania, Italy, Hungary), 100.000 as in Poland or Romania and 500.000 in Spain. In Latvia or Andorra one-tenth of the electorate is required" ${ }^{43}$. The example of Lithuania, Hungary and Italy, where the legal threshold of support is 50000, while the actual one is $1.789 \%$ in Lithuania and $0.512 \%$ in Hungary, and also $0.828 \%$ in Italy ${ }^{44}$ is noteworthy.

42 Former Yugoslav Republic of Macedonia.

43 Sergia Bartole, Angelika Nussbeger, Murielle Mauguin Helgeson, Report on legislative initiative, CDL-AD(2008)035-e, adopted by the Venice Commission at its $77^{\text {th }}$ Plenary Session (Venice, 12-13 December 2008). November 20, 2019, https://www.venice. coe.int/webforms/documents/CDL-AD(2008)035.aspx.

44 The number of residents as of 1 January, 2019 amounted to: Lithuania - 2794.2 thousand, Italy - 60359.5 thousand. Hungary - 9772.8 thousand, Eurostat data. 2019 . 
Table 4. Citizens' initiative at the EU, national and local level (Poland)

\begin{tabular}{|l|c|c|}
\hline \multicolumn{1}{|c|}{ Area } & Legal threshold of support & $\begin{array}{c}\text { Actual threshold } \\
\text { of support }\end{array}$ \\
\hline UE & $\begin{array}{c}\text { 1 million } \\
\text { EU citizens }\end{array}$ & $0.1950 \%$. \\
\hline Poland & 100,000 & $0.2603 \%$ \\
\hline $\begin{array}{l}\text { Voivodship } \\
\text { (largest) }\end{array}$ & Polish citizens who have the right to vote & $0.0185 \%$ \\
\hline $\begin{array}{l}\text { Voivodship } \\
\text { (smallest) }\end{array}$ & 1000 & $0.1013 \%$ \\
\hline $\begin{array}{l}\text { Poviat } \\
\text { (largest) }\end{array}$ & 1000 & $0.1281 \%$ \\
\hline $\begin{array}{l}\text { Poviat } \\
\text { (smallest) }\end{array}$ & 500 & $1.4391 \%$ \\
\hline $\begin{array}{l}\text { Municipality } \\
\text { (largest) }\end{array}$ & 300 & $0.36 \%$ \\
\hline $\begin{array}{l}\text { Municipality } \\
\text { (smallest) }\end{array}$ & 300 & $7.67 \%$ \\
\hline $\begin{array}{l}\text { City/town with } \\
\text { poviat rights (largest) }\end{array}$ & 300 & $0.0168 \%$ \\
\hline $\begin{array}{l}\text { City/town with poviat } \\
\text { rights (smallest) }\end{array}$ & 100 & $0.8322 \%$ \\
\hline
\end{tabular}

Source: Author's study. 


\section{CONCLUSION}

The conclusions of the analysis are as follows: first, it is "easier" for EU citizens to implement an initiative than it is for Polish citizens to submit a draft law to parliament.

Second, the lowest actual threshold of LCI support is applicable in Warsaw $(0.0168 \%)$ and the largest voivodship $(0.0185 \%)$, while the highest - in the smallest municipality $(7.67 \%)$ and the smallest poviat $(1.4391 \%)$. Submitting a draft resolution is most difficult in small municipalities. The actual threshold of support in a small municipality is 38 times higher than the threshold of support for a citizens' initiative in the EU and 28 times higher than the threshold of support for a nationwide initiative in Poland.

Third, signature requirements of the $\mathrm{CI}$ in the $\mathrm{EU}$ are low compared to small municipalities in Poland. Nonetheless, the EU CI is not particularly popular in comparison to petitions. "Initial enthusiasm about the ECI waned when it became apparent that the threshold for success was very high indeed. Since its introduction, just four initiatives have reached the required levels of support. The topics covered were water rights, protection of the human embryo, animal rights and a ban on glyphosate herbicides. In 2017, a review of the process was initiated"45. This last conclusion provokes sad reflections. Since the actual threshold of support of $0.1950 \%$ may be one of the factors that inhibit the development of the UECI, the more so the 7\% threshold, which in our view could have a freezing effect in small municipalities. It seems that the LCI could not achieve the assumed goal of activating citizens and increasing their participation in decision making at the local level. It also seems that the LCI could be an important instrument of participatory democracy in small municipalities, which rely on strong and close ties of residents. The smaller the municipality, the stronger the ties because they have been formed over generations, which is particularly evident in rural areas. In such homogeneous environments, the SR should be minimal. The above view is

45 Theresa Reidy, Paper of Dr. Theresa Reidy University College Cork Delivered to The Citizens' Assembly on 13 January, 2018. December 5, 2019, https://www.citizensassembly.ie/en/Meetings/Theresa-Reidy-Paper.pdf. 
supported by research conducted on the SR, yet at the level of national institutions: "It may suggest that the optimal requirement should be low for countries (or issues) in which the distribution of citizens' preferences tend to be homogeneous. In this case, citizens' opinions almost coincide and thus, the ratio of supporters becomes extreme. On the contrary, a high requirement is optimal in countries (or issues) where citizens have various opinions, in which case, for many laws, opinions are often divided. The intuition is as follows. If the distribution of supporters is extreme, there is a wide gap in collected signatures between good and bad laws. On the other hand, if the distribution is moderate, the gap is narrow. Therefore, in such cases, screening warrants a higher requirement" ${ }^{36}$.

Fourth, the above assertion concerning minimal SR for small communities (small rural municipalities) gains validity when juxtaposed with the subject matter of the LCI, e.g. changing a street name, building a water supply, bicycle path, building a kindergarten, etc. A question whether adraft resolution on changing a street name requires as many as 100 signatures ofresidents of a rural municipality is a legitimate one. On the other hand, one can reasonably ask whether the requirement of 300 signatures to change the name of a major thoroughfarein Warsaw, is not too low? Will such alow threshold not result in inflation of the LCI in Warsaw? Answers are yet to come since not all local government units have adopted resolutions setting out the rules and procedures for launching an LCI. And most importantly, there is no empirical data to assess how the institution in question functions in Poland.

\section{REFERENCES}

Bartole, Sergia, Angelika, Nussbeger, Murielle, Mauguin, Helgeson. 2008. Report on legislative initiative, CDL-AD(2008)035-e, adopted by the Venice Commission at its $77^{\text {th }}$ Plenary Session (Venice, 12-13 December 2008). November 20, 2018, https://www.venice.coe.int/webforms/documents/CDLAD(2008)035.aspx.

46 Tomoya Tajika, (2018), Signature Requirements for Initiatives, Journal of Theoretical Politics 30 (2018): 451-476. 
Christensen, Henrik, Serup, Maija Jäske, Maija Setälä, Elias Laitinen. 2017. The Finnish Citizens' Initiative: Towards Inclusive Agenda-setting?. Scandinavian Political Studies, 40: 411-433. DOI: 10.1111/1467-9477.12096.

Dryzek, John. 2009. Democratization as Deliberative Capacity Building, Comparative Political Studies, 42: 1379-1402. DOI: https://doi.org/ 10.1177/0010414009332129.

Ellis, Richard. 2003. Signature Gathering in the Initiative Process: How Democratic Is It?. Montana Law Review, 64: 35-64. December 4, 2018, https:// scholarship.law.umt.edu/mlr/vol64/iss1/4.

Geissel, Brigitte, Michels, Ank. 2018. Participatory Developments in Majoritarian and Consensus Democracies, Representation, 54: 129-146. DOI: http:// 10.1080/00344893.2018.1495663.

Gema, Sanches, Medero, Albaladejo, Gema y Pastor. 2018. The Quality of Participatory Processes in the Urban Redevelopment Policy of Madrid City Council. Lex Localis, 16: 841-872. DOI: http://10.4335/16.4.841-872.

Giżyńska, Monika. 2018. The Shortcoming of a Nationwide Referendum. Reflecting upon the Possibility of Introducing an Abrogative Referendum into the Polish Legal System, Toruńskie Studia Polsko-Włoskie XIV: 83-89. DOI: http://dx.doi.org/10.12775/TSP-W.2018.006.

Izdebski, Hubert. 2018. Prawne podstawy obywatelskiej inicjatywy uchwałodawczej. In: Obywatelska inicjatywa uchwałodawcza w procesie stanowienia aktów prawa miejscowego, Piotr Zientarski, Elżbieta Mreńca, ed., 13-22. Warszawa: Kancelaria Senatu.

Jać, Piotr. 2013. Obywatelska inicjatywa uchwałodawcza. In: Partycypacja obywatelska-decyzje bliższe ludziom, Agnieszka Maszkowska, Katarzyna Sztop-Rutkowska, ed., 141-148. Białystok: Fundacja Laboratorium Badań i Działań Społecznych "SocLab”.

Kaufmann, Bruno, ed. 2010. Podręcznik europejskiej inicjatywy obywatelskiej. Przewodnik po zasadach pierwszego ponadnarodowego narzędzia demokracji bezpośredniej na świecie. Luxembourg: Green European Foundation.

Kees, Koonings. 2004. Strengthening Citizenship in Brazil's Democracy: Local Participatory Governance in Porto Alegre. Biulletin of Latin American Research, 23: 79-99.

Lis-Staranowicz, Dorota. 2020. La proposta di deliberazione (a livello locale) di iniziativa popolare in Polonia. In: La democrazia diretta in Italia, Polonia e Unione europea, Gian Candido De Martin, Andrzej Szmyt, Piero Gambale e Maciej Serowaniec, ed., 541. Roma: Luiss University Press. 
Makowski, Grzegorz. 2012. Obywatelska inicjatywa uchwałodawcza - prawo i praktyka. In: Dyktat czy uczestnictwo? Diagnoza partycypacji publicznej w Polsce, Anna Olech, ed., 288-304. Warszawa: Instytut Spraw Publicznych. Pečarič, Mirko. 2013. Some Initiatives for Modernization of Local Democracy. Lex Localis, 11: 271-291. DOI: https://doi.org/10.4335/11.3.271-291(2013).

Piasecki, Andrzej. 2011. Twenty Years of Polish Direct Democracy at the local level. In: Local Direct Democracy in Europe, Theo Schiller, ed., 126-138. Wiesbaden: GWV Fachverlage GmbH.

Reidy, Theresa. 2018. Paper of Dr. Theresa Reidy University College Cork Delivered to The Citizens' Assembly on 13 January 2018. December 5, 2018, https://www.citizensassembly.ie/en/Meetings/Theresa-Reidy-Paper.pdf.

Ścisłowska, Anna, Waldemar, Duczmal. 2016. Obywatele piszą lokalne prawo? Dlaczego nie! December 29, 2019, http://serwis.mamprawowiedziec.pl/2016/11/ Obywatele-pisza-lokalne-prawo.html.

Tajika, Tomoya. 2018. Signature Requirements for Initiatives. Journal of Theoretical Politics, 30: 451-476. DOI: 10.1177/0951629818791035.

Turska-Kawa, Agnieszka, Waldemar, Wojtasik. 2018. Direct Democracy in Poland. Between Democratic Centralism and Civic Localism. Journal of Comparative Politics, 11: 18-29.

Uziębło, Piotr. 2009. Demokracja Partycypacyjna. Gdańsk: Centrum Badań Społecznych.

Ziętarski, Piotr. 2018. Aspekty aksjologiczne partycypacji społecznej a obywatelska inicjatywa uchwałodawcza. In: Obywatelska inicjatywa uchwałodawcza w procesie stanowienia aktów prawa miejscowego, Piotr Zientarski, Elżbieta Mreńca, ed., 23-37. Warszawa: Kancelaria Senatu.

Ziółkowski, Dawid. 2018. Obywatelska inicjatywa uchwałodawcza jako instrument partycypacji społecznej. Zeszyt Studencki Kół Naukowych Wydziału Prawa i Administracji UAM, 8: 331-344. December 3, 2018, http://cejsh. icm.edu.pl/cejsh/element/bwmeta1.element.desklight-12fe50bc-d98e-4660-b2bb-8bc0b2934c6e. 